\title{
JAPAN AND A NEW WORLD ECONOMIC ORDER
}

\author{
By KIYOSHI KOJIMA*
}

\section{Impact of the Oil Crisis}

The oil supply cutback by the Organization of Arab Petroleum Exporting Countries since October 1973 has had a profound impact on the Japanese economy. It over-reacted too seriously at first, since it depends almost entirely (up to 99.7 per cent) upon imported oil of which 81 per cent comes from the Middle East (and 40 per cent from the OAPEC countries). Japan's successful economic growth, especially rapid heavy and chemical industrialization, since the War has been sustained by access to a stable and cheap source of petroleum. Petroleum has been so much more economical and efficient than coal both as an energy source and a raw material, that Japan has reduced production of fuel coal to a negligible amount.

By now (March 1974) the panic reaction has calmed down. It has become obvious that the physical shortage of petroleum is only a short term phenomenon and that, in the long term, the price problem (with the posted price of crude rising four times the price in 1972 , to $\$ 11.651$ per barrel and the producing country government take to $\$ 7$ ) will be more difficult to solve. The abrupt rise of crude oil price is now bringing about a general inflation, first in the oil-related products, electricity, then other manufactured goods. This is compounded by a rise in wages. The Japanese economy has experienced a chaotic price-rise for the last few months since November 1973. It is inevitable that various prices be shifted to a higher level but it is hoped that an equilibrium price system will be established and then stabilized at that level within a few months.

It is crucially important for all oil-importing countries to try hard to reduce the oil-price to a more reasonable level (say 7-8 dollars at market price) in order to make payments for oil manageable. This is essential in order to avoid excessive strain on the balance of payments and disorder in exchange rates, in the international financial market, and in the international trading system (as will be touched upon later).

How can a reduction in oil-price be realized ? An excessively high price is brought about by the strengthened bargaining position of oil-producing countries in a seller's market. Their bargaining power should be softened or reversed. Developed oil-importing countries, including Japan, should economize on the use of oil as a short-run as well as a long-run measure: 10 to 20 per cent saving is not impossible. Some of the oil producers may then sell more oil at a more reasonable, lower price. It should be remembered that even the huge price rise of primary products at the time of the Korean War was curbed

* Professor $(K y \overline{o j} i)$ of International Economics. 
within two years.

As a long-run policy, Japan should transform her economic structure into a more oilsaving one than at present by moving ahead to knowledge-intensive industrialization. This target had already been set in 1971 by the MITI council ${ }^{1}$ but, the restructuring should be intensified and speeded up to deal with the problem of petroleum. It is envisaged that the elasticity of oil consumption to GNP, which has been falling from 2.5 since 1955-60, will decline to about unity. If this is realized, coupled with increased alternative energy sources, a 5-6 per cent annual increase of imported oil, which is not larger than in other developed countries, would 'make a 6-8 per cent growth of GNP possible (this is 1-2 percentage points lower than the Japan Economic Research Center forecast ${ }^{2}$ ).

Japan, along with other developed countries, will be prepared to expand considerable effort to develop alternative sources of oil supply since oil is, even at a higher price, the most economic of energy sources (except, perhaps, for solar energy) available to this import-dependent country.

If the present unreasonably high price of oil continues or rises further, developed countries, including Japan, will accelerate their efforts to find new oil sources or to develop alternative energy sources such as nuclear fission, the gasification of coal, the production of oil from sand oil and oil shale etc. Although it is not yet certain when alternative energy will be commercially produced, once production starts (within say 7-10 years) its cost will be low, due to economies of scale, resulting in overproduction of energy as a whole and a reduction in the price of oil as a long-run trend. An excessively high price of oil may rapidly make oil obsolete and reduce, rather than increase, total revenue over the period until oil is exhausted. This must be of great concern to oil producing countries and one of the reasons for persuading them to reduce oil-prices to a reasonable level.

It should be remembered that the non-oil producing developing countries have been severely hit by the quadrupling of oil prices. The extra oil payments for 1974 amount to more than $\$ 10$ billion which surpasses the official development aid that they receive. The shortage and the rising price of chemical fertilizers, plastics and other intermediate goods hinder their industrialization and food production. Furthermore aid might be reduced as a result of the balance of payments difficulties of donor countries and markets for their exports might narrow because of reduced economic activity in developed countries.

The Arab countries' desire for industrialization involves a lot of difficulties too. It is right that they should try to find means to live and to prosper before oil is exhausted. However each of the Arab countries plans to establish almost the same type of oil-based industries (e.g. oil refinary, petro-chemicals, chemical fertilizers, production of steel and aluminium using cheap natural gas, etc.). Many of the Arab countires are sparsely populated. They will need huge markets outside the Arab area. Furthermore, competitive production of refined petroleum goods in Arab countries might make their price cheaper than crude oil for which outside demand continues to increase. Contrary to the Arab's wish, when oil dries up, oil-based industries will also cease to be prosperous.

Arab countries should plan more carefully their steady economic development which, anyway, will take time, and they should take into consideration, firstly, economic coope-

\footnotetext{
${ }^{1}$ Ministry of International Trade and Industry, Trade and Industrial Policy in 1970s, May 1971.

2 Japan Economic Research Center, Japan's Economy in 1980 in The Global Context, Tokyo, March 1972.
} 
ration and integration within the Arab area, secondly interdependence with the rest of the Third World's development, and, lastly, complementarity with advanced industrial countries.

Thus, it becomes an urgent and fundamental task for Japan and other developed countries in the 1970s to promote the steady economic development of developing countries, including the Arab oil producers, and to reorganize North-South trade on an harmonious and prosperous basis. A grand integrated policy of aid-investment cum preferencesstructural adjustment should be developed. ${ }^{3}$

The oil crisis has created another difficult problem, that is, how to handle the huge oil revenues which Arab countries receive so as not to disturb international financial and trade order.

\section{Tokyo Round of Multilateral Trade Negotiation}

A new round of multilateral trade negotiation in GATT has been started by the declaration of ministries approved in Tokyo on 14th September 1973 and a fortnight later at the IMF general assembly in Nairobi. This is a step towards the reform of the international monetary system within a year or so. A new world economic order, both in trade policy and monetary system, is urgently demanded in order to get rid of the turmoil since August 1971 and of the fear of a potential crisis like the 1930s, and in order to build a second Bretton Woods system for the prosperity of all nations in the world. But the emergence of the oil-crisis since October 1973 has added another difficulty and disturbed the steady movement towards a new world economic order.

The steady liberalization of world trade since 1945 has played an integral role in the unparalleled growth in world production, employment and prosperity which virtually all nations have enjoyed since that time. "It therefore noted with deep concern that much recent discussion, the trend in recent years toward a proliferation of new trade barriers and other distortions of trade, and the breakdown in international law as it bears on trading relationships among nations appear to overlook the enormous benefits which the high level of international trade has secured to national economies, the fragility of the system unless it is maintained and strengthened, and the high cost if it is seriously impaired under the pressure of temporary but remediable difficulties. The group concluded that there was serious risk that these trends might continue, and that it was urgent to stop them for several reasons." 4

Japan, as the host country and with a background of a favourable balance of payments, expressed a positive attitude as follows:

i. With regard to tariffs, we are of the view that elimination of tariffs should be adopted as the long-term objective, and, in line with this objective, substantial reduction of tariffs be realized.

\footnotetext{
${ }^{8}$ See, Kiyoshi Kojima, "The Japanese Experience and Attitudes toward Trade Adjustment," in Helen Hughes, ed., Prospects for Partnership: Industrialization and Trade Policies in the 1970s, World Bank Publication, Johns Hopkins, 1973, pp. 228-262.

The Maidenhead Communique, issued on April 12, 1973 by twenty businessmen, economists, and labour union officials from Japan, North America and Western Europe.
} 
ii. With regard to non-tariff measures: these measures, or their trade-distorting effects, should be reduced or eliminated as far as possible.

iii. As for safeguards: we believe that multilateral safeguards should be examined, keeping in mind the principle of non-discrimination and with a view to seeking the further promotion of trade liberalization and to preserving the results thereof.

iv. With respect to trade in agricultural products: it is our view that we should seek, in line with the general objectives of the negotiations and considering the special character of the agricultural sector, a steady expansion of agricultural trade under stable market conditions based upon mutual benefits through cooperation between exporting and importing countries. ${ }^{5}$

We envisage many difficulties in the negotiations, however, except for fairly easy progress in setting up rules on such technicalties as customs procedure and valuations, industrial standards and safety regulations, etc. Furthermore, specially favourable treatment to developing and least developed countries involves a contradiction of the GATT principle of non-discrimination and discourages the reduction of trade barriers among advanced countries. The elimination of tariffs is preferable and the phasing-out of preferential trade arrangement is inevitable for the latter is not effective and merely discriminates in favour of the industrialized developing countries. Perhaps no important progress will take place until the oil crisis has been resolved. This is applicable also to the reform of the international monetary system.

\section{A Fair-Weather Rule}

Perhaps, the present world needs a brave attempt to find new directions for GATT. Therefore, I would like to issue briefly my thoughts as an economist on world trade policies with special reference to the coming GATT negotiation, mainly from Japan's point of view and without due consideration of feasibility or legality.

The starting point of my observation is to ask whether the remaining tariffs and nontariff barriers are really large and still deterrent to trade expansion. Legally, the answer is yes. Practically, it can be said that trade liberalization has been almost finalized. Even in the 1860s free trade was never complete. The present remaining tariffs and NTBs appear to be large because comparative cost differences in manufactured trade have become much narrower than those in 19th century vertical trade but, in fact, they are not large barriers and can be easily overcome by export efforts.

In the present situation, in which only a hard core of trade barriers is retained in each country, it should be asked whether it is right to push hard for further trade liberalization in the coming GATT negotiation or whether we should rather stop the "liberalization war" and wait for the effect of monetary realignments to become more obvious. To attack partner country's hard-core barriers in the present situation may be merely to invite antagonism and resentment. Usually, in order to eliminate hard-core barriers, GATT nagotiation is useless and domestic structural adjustment in each country and harmoni-

Statement by the Japanese Representative, Mr. Z. Kosaka, Minister for Economic Planning at the GATT Ministerial Meeting in Tokyo, September 12, 1973. 
zation of domestic policies between them are indispensable. A complete reorganization of GATT into a new organization a la larger headquarter of the European Community might be required - this is unquestionably difficult.

Therefore an attempt to reduce by half the present low levels of tariffs (less than 10 per cent on average) in advanced countries does not present an attractive target when the time and labour required are compared with the expected result. Rather, a complete and stage-wise elimination within say, ten years, of tariffs on manufactured goods should be aimed at. If this were attained, many non-tariff barrier problems such as customs valuation and procedures, tariff preferences of custom unions and preferences toward developing countries, etc. would automatically disappear.

Although the Japanese government and business circle stressed the difficulty of reducing tariffs during the Kennedy Round negotiation, it could, in fact, be done without any difficulty or harm to our national economy (this remark is applicable not only to tariff reduction. but also to the gradual elimination of quota restrictions and to the revaluation of the yen). On the contrary, Japan benefited considerably from the Kennedy Round tariff reduction. In October 1972, the Japanese government unilaterally reduced tariffs by $20 \%$ on almost all manufactured imports. If we could do this then why couldn't we implement gradually a 100 per cent tariff cut? The reduction of the escalation of the tariff system will also be completed very soon. In the EEC and EFTA, they were able to eliminate intra-areal tariffs. There is, perhaps, no reason why they could not abolish external tariffs as well.

In order to bring about a substantial abolition of non-tariff barriers and a furtherance of tariff reductions, it is necessary to change the mistaken concept of "national interest" in which exports are gains and imports losses. The true concept of the gains from trade is that the real gain is to import cheaply and in great quantity, while exports, which are not a gain per se, should reach the level where they can finance imports efficiently. Japan will have to shift its objectives towards the realization of this true gain from trade. Needless to say, such a conversion of philosophy is required not only of Japan but of all other countries too. Dismantling of non-tariff barriers and tariff reduction will not be realized unless all countries act voluntarily, on the basis of the true concept of gains from trade, irrespective of what their partners do.

It is not only in regard to trade that the change of philosophy is necessary. Too many resources have been poured into export activities in Japan. Furthermore, import restrictions have acted to protect less efficient industries within the country. In this way the Japanese economy attained and maintained full employment and has continued to grow at a rapid pace. As compared with a possible state of the nation in which the optimal allocation of resources had been attained, industrial efficiency and the welfare of the people have been distorted. Abandoning the pursuit of mere high growth of aggregate national product irrespective of its quality and content, Japan ought to change its philosophy towards the attainment of economic growth by utilizing its resources more efficiently.

It is time to expect a unilateral reduction and elimination of trade barriers from each country in its own interest, i.e., in order to achieve better re-allocation of resources, to curb inflationary pressures, and so forth. ${ }^{6}$ All nations should get rid of a mercantilistic attitude.

${ }^{6}$ The Maidenhead Communique mentioned above recommends unilateral elimination of trade barriers. 
This is especially needed in the case of non-tariff barriers. Non-tariff barriers can hardly become a subject of bargaining in accordance with the principle of reciprocity since they are not measurable in their effect, not comparable to each other and differ from each other by country in their motivation and intent. However, such a rule as "over time reciprocity" might be established in order to facilitate unilateral, stage-wise trade-liberalization.

I would like to propose to the GATT "a fair weather rule of reduction (or elimination) of tariffs and non-tariff barriers." That is, a country should reduce tariffs and NTBs while its balance of payments is favourable, but it should not be allowed to raise them again even if its balance of payments becomes unfavourable since at that time some other country will have a favourable balance of payments and will be expected to reduce its own tariffs and NTBs. In this way, "over-time reciprocity" is assured and tariffs and NTBs of all advanced countries will be eliminated gradually within, say, 10 years. ${ }^{7}$ The fair-weather reduction rule may be implemented in a more detailed fashion as a counterpart to the exchange-rate adjustment rule which is now under discussion with regard to international monetary reform.

What foreign countries should ask of Japan now is, instead of hasty further liberalization of non-tariff barriers, a) monetary realignment up to an appropriate exchange rate, b) domestic structural adjustment so as to increase imports of manufactured goods, and c) diversification of consumption tastes. The most pursuasive reason for undertaking these, together with unilateral tariff reduction and further liberalization of non-tariff barriers, must be that they will contribute to curing inflationary pressure.

All countries should abolish non-tariff barriers, which are direct and selective restrictions on trade, as soon as possible and shift to the tariff system. If it is possible to measure the tariff equivalent effect of non-tariff barriers then there is no reason why a shift to tariff systems is impossible. If it is not possible to measure such an effect then it might be well to permit countries to levy or raise tariffs to the extent that they can feel safe or secure by doing so. This might be unavoidable even if it temporarily raises tariff barriers to some extent. However, after it will eventually be proven and recognized that high tariffs are unnecessary. Then it might be appropriate to set about a Kennedy Round type tariff cutting negotiation. This method, as suggested by some experts, ${ }^{8}$ is worth thorough consideration.

\section{A New Safeguard}

Although free trade is beneficial for the whole national economy, individuals within each country can be hurt as a result of trade flows. Complementary policies are needed to give those individuals who are displaced time to adjust to the new conditions and to

\footnotetext{
${ }^{7}$ The Japanese government supports the gradual elimination of tariffs but insists that negotiations be conducted in accordance with the provisions of the GATT including those on most-favoured nation treatment, and on the basis of the principles of mutual benefit and overall reciprocity. It is a question of whether my "over time reciprocity" is taken as a concept of "overall reciprocity."

s See Gerard and Victoria Curzon, Hidden Barriers to International Trade, Trade Policy Research Centre, London, 1970, p. 63; Harold B. Malmgren, Trade Wars or Trade Negotiation? The Atlantic Council of the United States, Washington, D.C., 1970, pp. 66 and 70.
} 
help them do so. These policies should be of two types: 1) temporary limitations (safeguards) on the rate of imports which rise too rapidly to be readily absorbed, and 2) government assistance to help affected individuals adjust comfortably to the new circumstances. However, there is great concern that the safeguards may easily be abused for protectionistic purposes. It is in Japan's interest that, as an amendment to Article XIX, the safeguard clause should include an obligation that "application of the safeguard measures should be accompanied by action to bring about domestic adjustment so that the use of the safeguard mechanism will in fact be temporary."9

The Maidenhead Communique defines this more precisely as follows:

"Temporary limits on the growth of imports should be avoidable in cases where examination of all relevant facts shows clearly that injury to firms and workers beyond their capacity to adjust with reasonable assistance, has been caused by imports. Such restrictions should be strictly limited in duration and degressive over time. In addition, an adjustment program which will enable the injured either to continue their present occupations or shift into new endeavours should accompany any such import limitations, to permit these limitations to expire on schedule. All these features of a new safeguard should be subject to international surveillance. The new system should cover all policy instruments used to restrain trade, including the so-called "voluntary" export restraints which have heretofore operated outside any international framework." 10

Perhaps sharp increases in Japan's (and some developing countries') exports of particular goods to particular markets are the object of the new safeguards. Japan must reconsider since this reaction is, the result of the Japanese style of export competition. Once export of a particular commodity to a particular market is alledged to be promising firms follow each other blindly, flooding the market and waging a cut-throat price war. To cope with such practices control, through use of minimum export prices, might be most useful. Another cause of excessive competition in export markets was export credit incentives. On domestic sales it takes a considerable time to collect bills. In the case of exports, exporters were able to get payment immediately after shipment of goods by discounting bills at subsidized interest rates. Therefore, the abolition of export interest subsidization which has been carried out will help to prevent excessive export competition.

Japan, herself, needs and will agree to a new safeguard for she will face a sharp increase in imports from developing countries in the not too distant future, but she strongly insists, as shown in the last Tokyo meeting, that safeguards should be multilateral and non-discriminatory. In other words, Japan cannot accept safeguards under bilateral treaties which exist between Japan and some European countries, the United Kingdom, France and Benelux, and such safeguards as perhaps the EC has in mind which discriminate against a specific country (perhaps Japan).

Export embargoes on petroleum, grains and other primary products are of great concern to the Japanese economy which depends heavily upon imports from abroad in essential raw materials and food. At present we do not know how to deal with such a situation.

\footnotetext{
${ }^{9}$ OECD, Policy Perspective for International Trade and Economic Relations, Paris 1972, p. 84.

${ }^{10} \mathrm{See}$, also, World Trade and Domestic Adjustment, A tripartite report by fourteen economists from Japan, he European Community and North America, The Brookings Institution, 1973, pp. 17-18. $\mathrm{t}$
} 
Retaliation may not only be ineffective but also result in the multiplication of trade barriers.

In addition the establishment of rules of free trade which will merely assure a static optimal resources allocation is not enough. Comparative costs of various countries change as time goes on. Measures have to be provided which would promote dynamic, longterm optimal resource allocation. The protection of infant industries is justified from such a dynamic viewpoint. If this is recognized then policies aimed at structural adjustment and assistance in shifting resources from mature and declining industries to those which are gaining comparative advantage should be internationally approved and instituted.

Instead of harshly attacking other country's trade barriers, we should look for a dynamic outlet for increasing world trade and appropriate measures for this purpose should be built in to the GATT rules. Possible policies which come to mind are the creation of new products and a new growth center in the world trade, structural adjustment to changing comparative advantages, agreed specialization in those products in which economies of scale dominate costs of production, and better utilization of foreign direct investment.

\section{A Bifocal Key-Currency System}

The ideal is that trade barriers should be confined to tariffs and that the adjustment of international balance of payments be left with overall adjustment measures. However, the reality is that the overall adjustment measures per se do not work promptly and effectively with the result that some countries have an unfavourable balance while others have a favourable balance for a prolonged period. Hence the difficulties in removing non-tariff barriers and the fears that they might, instead, be increased. Therefore, more than anything else, the streamlining of the international monetary system and foreign exchange rates so that overall adjustment measures can function promptly and effectively is necessary. Though it is not necessarily clear what sort of cooperative relation exists between the GATT and the IMF, it is difficult to see how trade liberalization can be negotiated with GATT as its focus and how it can be promoted by means of tariff cuts or reduction and removal of non-tariff barriers without regard to the international monetary situation. It should be remembered that if the latter is in a state of confusion the liberalization of trade can only regress.

The Tokyo GATT ministerial meeting declared, after a long discussion between the U.S.A. and France, that "The policy of liberalizing world trade cannot be carried out successfully in the absence of parallel efforts to set up a monetary system which shields the world economy from the shocks and imbalances which have previously occurred. The ministers will not lose sight of the fact that the efforts which are to be made in the trade field imply continuing efforts to maintain orderly conditions and to establish a durable and equitable monetary system. The ministers recognize equally that the new phase in the liberalization of trade which it is their intention to undertake should facilitate the orderly function of the monetary system." 11

In the near future, it is almost certain that effective new rules and procedures to assure sufficiently prompt adjustment of payments imbalances by both surplus and deficit coun-

\footnotetext{
${ }^{11}$ Declaration of Ministries, approved at Tokyo on September 14, 1973, Ministerial Meeting, GATT.
} 
tries will be set up. The new rules would be exchange parities subject to frequent and relatively small adjustment according to some objective indicators, with provision for wider margins and options for temporary floats under appropriate circumstances.

More fundamental reform in the international monetary system may not be easy and will take a longer time, for the United States supports the present floating exchange rate system as a means of continuing her "benign neglect" policy whilst the EC and/or Japan is/are not ready to assume the responsibility of being a competitive reserve center.

Personally I envisage, as a longer-run plan, a bifocal key currency system ${ }^{12}$ between the dollar and the "Eurco" (European Composite Unit) which will be established before long under the European currency integration scheme. ${ }^{13}$ Both currencies set par value in terms of numeraire, gold and revised SDRs, and therefore, are used as reserve assets, intervention currencies and vehicle currencies. The exhange rate between the two key currencies is adjustable according to the new rules of exchange adjustment. But adjustment should be in such a way that both sides would share the burden of adjustment equally through revaluing the surplus currency and devaluing the deficit currency so that the value of key currencies taken together be kept constant in terms of the numeraire.

If the surplus side wants to avoid revaluation or make it smaller, it has to buy new SDRs from the IMF. International liquidity should not be increased either through the balanceof-payments deficit of a key-currency country, as it was under the dollar standard, nor through arbitrary control without any backing as it has been in the present SDRs. Rather international liquidity should be increased through investments on new SDRs by the surplus country.

If the deficit side wants to avoid devaluation or make it smaller, it has to borrow new SDRs through the IMF and to submit to international surveillance by the IMF.

Because of the competition between the two key-currencies, the result of which is well shown in the cross-rate between them, the two sides are forced to follow monetary and balance of payments discipline. In addition, third countries have freedom as to which key currency they choose as a peg, in what proportion they hold the two key currencies and even to switch the key currency to which they peg. Third countries have to adjust exchange rates according to the new rules when they fall into payments disequilibrium in relation to the pegged currency. Thus, the behaviour of these third countries enforces further discipline of the key currency countries.

Some advocate that Japan should establish a yen currency area. ${ }^{14}$ I think this is quite premature. For the competitive key currency system, bifocal currencies are enough. Japan might do far better to remain under the umbrella of the dollar. ${ }^{15}$

\footnotetext{
${ }_{12}$ As regards detailed explanation, see, Kiyoshi Kojima, "A Competitive, Bi-focal International Monetary System" (1n Japanese), The Hitotsubashi Review, November 1973, pp. 1-16.

Cf. Robert A. Mundell, "A Plan for a European Currency," H.G. Johnson and A.K. Swoboda, ed., The Economics of Common Currencies, George Allen \& Unwin, London, 1973.

13 France's withdrawal from the EC common float in January 1974 cast doubt on the solidarity of European currency integration, although the use of gold as a means of regional settlement may facilitate Europe's development as an international reserve center.

it See, for example, Nihon Keizai Chosa Kyogikai, A New International Monetary System and the Yen, Tokyo, July 1973.

${ }_{15}$ It seems to me that the Japanese government, following the United States view, believes in and supports a SDR standard although details of its plan are unclear. Personally I dislike the scheme for SDRs which, lacking any solid backing, cannot solve the "confidence" problem while SDRs cumulatively increase in volume.
} 


\section{The Recycling of Oil Money}

As a result of the emergence of the oil crisis and the anticipated accumulation of "hot" oil money it is proposed, on the one hand, that international monetary reform should be carried out rapidly so that the "oil-dollar" problem may be settled within that context and on the other, that monetary reform is not possible until the oil-dollar problem has been solved. Perhaps for the coming one or two years, the present system of managed floats and a de facto dollar standard will be maintained.

What is shocking is the hugeness of the increased oil revenues which are said to be at least $\$ 60$ billion for 1974 and are expected to increase annually. It is a most urgent task for oil consuming countries to reduce oil prices to a reasonable level and, thus, total payments to a manageable sum.

How big a disturbance the excess oil revenue will bring about on the international financial market would depend entirely on what the oil exporters decided to do with the additional proceeds: what proportion would be spent on imports (which could not be large), what proportion would be held in liquid reserves and in what other kinds of reserve assets, and, finally, what proportion would be invested on a long-term basis, and in what countries and what types of assets.

What is essential is international action to reduce the percentage of "hot" money by attracting oil dollars into long term funds and investments. Unless this can be done such international disorder as competitive exchange devaluation and import restrictions for the sake of individual country's balance-of-payments difficulties will be unavoidable.

First, long-term investment by oil producing countries in their own economic development and in that of other non-oil-producing less developed countries through the world Bank and other areal Development Banks, is most desirable. But this alone would not be large enough since this type of investment is risky and economic development takes time.

Second, as Witteveen, Managing Director of the IMF, proposed, investment or deposit of oil producing countries' monies in the IMF special fund, through which SDRs are created, is also desirable. But Arab countries may distrust the future value of SDRs and prefer gold and/or the stronger currencies. Therefore, this demands the establishment of a sound international monetary system and that a new SDR must be backed by gold and strong key currencies as I have proposed.

Practically speaking, major recycling of the excess oil revenues may be carried out through the Euro-money and New York markets. But this involves much uncertainty and disturbance in international finance, in exchange rates and in the trading system.

The problem of recycling will have to be approached in a number of different ways, since no single solution seems likely to suffice. For the coming one or two years, until a sound international monetary system is re-established, it might become unavoidable to pay some portion of the bill for imported oil with gold at market price and high yield national bonds. 